\title{
PRODUCTION AND WASTE OF MINERAL RESOURCES AND THEIR BEARING ON CONSERVATION
}

\author{
By J. A. Holmes,
}

Chief, Technologic Branch, U. S. Geological Survey; member of National Conservation Commission, Washington, D. C.

The study of the problem of conservation with reference to mineral wealth is easily separable into two divisions, considering under one the mineral resources as they exist to-day, and under the other a study of the production, consumption and waste of these resources and the prevention of this waste. The former of these is discussed in another paper in this volume by the Director of the Geological Survey. In discussing the latter in the following pages but brief consideration can be given to each phase of the subject. The mineral products in the United States for the year 1907 exceeded $\$ 2,000,000,000$ in value. It is estimated that the waste in the mining and use of these materials is equivalent to more than one-fourth of this amount, exceeding $\$ 1,500,000$ per day. ${ }^{1}$

The Larger Contributors to Our Mineral Wealth.-The following are a dozen of the largest individual contributions to this $\$ 2,000$,000,000 addition to the nation's wealth during 1907 in the form of crude mineral products, the values given being those at the mines or works :

Coal, $480,000,000$ tons, with a value of $\ldots \ldots \ldots \ldots \ldots \ldots \ldots \ldots \ldots+\ldots 15,000,000$

Iron ore, $52,000,000$ long tons, valued at................. I32,000,000

Pig iron, $26,000,000$ long tons, valued at................. 530,000,000

Copper, $869,000,000$ pounds, valued at.................. $174,000,000$

Clay products, valued at.......................... $159,000,000$

Petroleum, I66,000,000 barrels, valued at................ I20,000,000

Gold, $4,375,000$ ounces, valued at $\ldots \ldots \ldots \ldots \ldots \ldots \ldots \ldots .69,0,000,000$

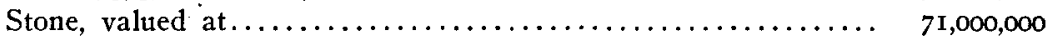

Cement, $52,000,000$ barrels, valued at.................... $56,000,000$

Natural gas, valued at $\ldots \ldots \ldots \ldots \ldots \ldots \ldots \ldots \ldots \ldots \ldots . \quad 53,000,000$

Lead, 365,000 tons, valued at...................... $38,700,000$

Zinc, nearly 224,000 tons, valued at................... 26,400,000

Phosphate rock, $2,265,000$ tons, valued at................. I0,650,000

1The statistics of mineral production given in this paper are taken mainly from the reports of The Mineral Resources Division of the U. S. Geological Survey.

(686) 
The total value of our non-metallic products during 1907 was more than $\$ 1,166,000,000$. Of this, the fuels (coal, petroleum and natural gas) approximated $\$ 788,000,000$; structural materials (clay products, stone, cement, lime, slate, etc.), nearly $\$ 306,000,000$; abrasive materials (grindstones, oil stones, garnet, quartz, feldspar, infusorial earth and tripoli, millstone, corundum and emery), about $\$ 1,647,000$; chemical materials (phosphate rock, salt, sulphur, gypsum, borax, pyrite, fluorspar, etc.), nearly $\$ 30,760,000$; pigments (zinc white, mineral paints, barytes, etc.), nearly $\$ 9,762,000$; and other miscellaneous mineral products (moulding sand, glass sands, mineral waters, asphalt, precious stones, talc, tungsten, feldspar, bauxite, mica, fullers' earth, etc.), about $\$ 30,387,000$. The total value of the metallic products (iron, copper, gold, lead, silver, zinc, aluminum, quicksilver, tin and platinum) for the same year was $\$ 903,000,000$. Of this total mineral production in the United States we exported during 1907 mineral products to the value of $\$ 347$,000,000 . This was in part offset by the importation of mineral products to the value of $\$ 225,000,000$.

The value of mineral products consumed in the United States during 1907 was, therefore, $\$ 2,191,000,000$, or $\$ 122,000,000$ in excess of the production.

American Contributions to the World's Mineral Production.The value of mineral production in the United States as compared to that in other countries is indicated by the fact that during 1907 the United States produced 63 per cent. of the world's petroleum, nearly 55 per cent. of its copper, $5^{2}$ per cent. of its phosphate rock, 46 per cent. of its steel, 43 per cent. of its cement, 40 per cent. of its iron ore, 40 per cent. of its coal supply, 33 per cent. of its lead, 30 per cent. of its silver, more than 27 per cent. of its zinc, and 22 per cent. of its gold.

Rapid Growth of Our Mineral Production.-There are few better illustrations of the rapid development of this country than the growth of this mineral production. Thus, in 1880 , the value of the mineral products in the United States approximated $\$ 365,000$,000 ; in $1890, \$ 606,000,000$; in $1900, \$ 1,107,000,000$; in $1907, \$ 2,069$,000,000 . The total value of the mineral products for the ten years, 1880 to I 889 , inclusive, was $\$ 4,478,000,000$; that for the ten years 1890 to 1899 , inclusive, was approximately $\$ 6,594,000,000$; whereas that for the eight years from 1900 to 1907 , inclusive, was $\$ 12,025$,- 
ooo,000. If the mineral production for 1908 and 1909 approaches $\$ 2,000,000,000$ for each year we shall have for the thirty years, beginning with 1880 , a total mineral production of approximately $\$ 27,000,000,000$.

The following table indicates by years the rapid increase in value of the crude mineral products for the United States:

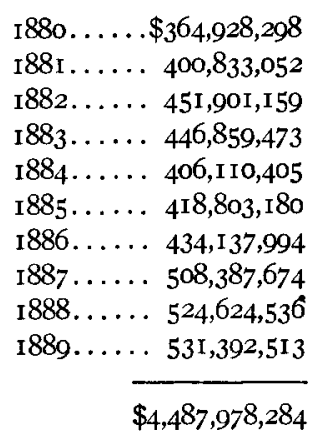

$$
\begin{aligned}
& \text { I890 . . . . . \$606,476,380 } \\
& \text { I } 891 \text {. . . . . 6 605,385,029 } \\
& \text { I } 892 \ldots . . .622,543,38 \text { I } \\
& \text { I } 893 \ldots . . .545,693,967 \\
& \text { I } 894 \ldots \ldots 549,374,767 \\
& \text { I } 895 \ldots . .6640,77 \mathrm{I}, 528 \\
& \text { I } 896 \ldots . . .640,544,221 \\
& \text { I } 897 \ldots . .6646,992,582 \\
& \text { I } 898 \ldots \ldots .724,272,854 \\
& \text { I899 . . . . . I,0I4,355,705 } \\
& \$ 6,594,410,414
\end{aligned}
$$

As indicated by the figures given above, the estimated value of mineral products for the current decade is nearly two and one-half times that for the preceding decade, and the coal production alone for 1907 exceeded in value the total mineral production for any year prior to 1892 . Still more striking are the figures indicating our per capita value of the mineral products, which in I880 were $\$ 7.25$; in $1890, \$ 9.68$; in $1900, \$ 14.55$, and in 1907 , \$24.19.

Production, Waste and Duration of Fuel Resources.--Unlike the supply of water, which goes and comes perennially, or of farm crops, which annually succeed one another, or even of the forests, which may come in succession with longer intervening periods, the supplies of mineral resources are limited, and they can neither be increased nor reproduced. Our mineral fuels deserve special consideration in this connection for the further reason that their use involves their immediate and complete destruction; and the increase in the manufacture and use of other materials also increases the consumption of fuels for heat, light and power, and for metallurgical purposes. Considerations such as these warrant special attention being given to the fuel problem in any discussion of conservation.

2Estimated. 
From the beginning of our records of coal mining in the United States, about I8I4, to the close of 1907 there were mined nearly $7,000,000,000$ tons of coal. During this time the waste in mining probably exceeded $3,500,000,000$ tons. The average rate of increase in production from 1846 to the close of 1907 was 7.36 per cent. per annum. The rate of production, however, has been a slightly decreasing one. Taking this and other factors into consideration, the experts of the Geological Survey have estimated that if this growing rate of consumption continues, the easily accessible and available coal supplies, aggregating $\mathrm{I}, 400,000,000,000$ tons, will be exhausted before the middle of the next century. As to whether or how long this increasing rate of production and consumption will continue there may be reasonable differences of opinion. The estimates are based on the experience and development of the nation during the past three-quarters of a century, including its tendency toward an increasing per capita consumption of fuel. ${ }^{3}$

However, the time of this exhaustion will be naturally postponed by virtue of the fact that long before exhaustion would be reached the increasing scarcity and the higher price of fuel would cause a lessening in its rate of consumption. Furthermore, the adoption of more efficient methods in connection with the mining and use of coal, and the larger use of water power and other possible substitutes for coal, may serve to diminish the present increasing rate of consumption and thereby extend the life of the supplies. On the other hand, manufacturing in this country will doubtless long continue to.grow more rapidly than the population, and the tendency will be to increase the demand for coal.

The waste of coal, both in mining operations and in use, is far greater than it should be. From the beginning of our mining operations down to the present time the average loss in the mining of bituminous coal has probably exceeded 50 per cent. of the total production. During the last few years, however, both in the anthracite and high-grade bituminous coals, in a number of our Eastern coal fields the loss in mining has been-reduced to smaller percentages. In portions of the central and Western coal regions the percentage of loss still exceeds 50 per cent.

The losses in the use of coal for different purposes cannot be estimated with accuracy, but that these losses are serious is indi-

sSee also page 210. 
cated by the fact that in the power plants of the country less than Io per cent. of the heat value of the coal is converted into actual work, and lighting plants convert less than I per cent. of the heat value of the coal into electric light. Large amounts of gas from our blast furnaces are lost by being turned into the atmosphere. To a small but increasing extent, however, these gases are being transformed into power through the use of gas engines. In connection with the coking industry gases and other by-products to the value of more than $\$ 55,000,000$ were wasted in 1907 .

Of petroleum the total production during the last half century has exceeded I,800,000,000 barrels. The rapidly increasing rate at which this production has been obtained and a careful study of the existing known petroleum supplies indicate the probable exhaustion of these known supplies before the middle of the present century. It is probable, however, that the life of the petroleum industry will be largely extended through the discovery of other supplies, as well as through a more efficient use, and, therefore, a lessening in the rate of increase in the demand for existing petroleum products.

The loss or waste of petroleum is proportionately far less than that of .most other mineral products. It is unfortunate, however, that so large a proportion of this material which is invaluable for illuminating and lubricating and other specific purposes should be so extensively used as fuel in locomotives, steamships and other power plants. The consumption of petroleum for fuel purposes during 1907 exceeded $35,000,000$ barrels.

Concerning the production of natural gas existing records are incomplete. For the twenty years from 1888 to 1907 , inclusive, the value of the natural gas recorded was a little more than $\$ 493,000,000$. The waste of this material has been enormous. The gas wasted has greatly exceeded that which has been used. More care is exercised now than was formerly the case to prevent the waste and provide for the efficient use of natural gas, but it is estimated that even at the present time the daily loss of gas is not less than $\mathrm{I}, 000,000,000$ cubic feet, or equivalent to 143,000 barrels of petroleum, and in one field, the Caddo field of Louisiana, the daily loss of gas is now not less than $70,000,000$ cubic feet, enough to light ten cities the size of Washington, and equivalent to a waste of 10,000 barrels of petroleum per day. 
Production and Waste of Metallic Resources.-In a brief paper, a discussion of this character may be limited to iron and steel and a few major metals, such as copper, gold, silver, lead and zinc.

The production of iron ore in the United States has increased with a rapidity as striking as that in the case of coal. The production for ten years, from 1870 to 1879 , inclusive, was more than $40,000,000$ tons. For the ten years 1880 to 1889 , inclusive, it was nearly I02,000,000 tons; from I890 to I899, inclusive, nearly I84,ooo,ooo tons, and from I900 to $1909,{ }^{4}$ inclusive, more than $445,-$ 000,000 tons. This is an average increase by decades of more than Ioo per cent. Even with the enormous supplies of iron ore known to be available for future use, at this increasing rate of consumption these supplies cannot be expected to meet the demands of the nation for an indefinite period. Indeed, it is probable that the supplies of high-grade iron ores will be exhausted and large inroads made on the supplies of lower grade ores before the end of the present century.

The fact that iron and steel, unlike our fuels, are not fully destroyed in use, but accumulate in a measure as one of our national assets, will doubtless in the course of a few generations reduce the present increasing per capita rate of production and consumption of these materials.

Fortunately, there is in the present methods of mining and treatment but little waste in the handling and treatment of the iron ores. Notably, in the Lake Superior districts not only are the highgrade ores gathered with care, but also the ores of lower grade are segregated in such manner as will permit of their easy recovery at such time as their use may become practicable. In some of the other fields the ore waste is greater, but not comparable with prevailing fuel waste, and the losses of iron in modern furnace practice are insignificant. The most serious sources of waste in the supplies of iron and steel are in the losses of the finished metal in use, through wear and through rust and other destructive agencies. These losses are permanent, are increasing and are believed to be largely preventable.

The production of gold increased rapidly from the middle of the last century, but dropped from $\$ 60,000,000$ in $185^{2}$ and 1854 to $\$ 30,000,000$ in 1883 , and subsequently increased to its maximum of

4Production for 1908 and 1909 being estimated.

(69I) 
more than $\$ 94,000,000$ in 1906 . The production of gold $^{5}$ in the United States from $I 792$ to $I 847$ was $\$ 24,537,000$; from $I 848$ to I872, $\$ 1,204,750,000$, and from 1873 to $1907, \$ 1,741,784,000$. The total production of gold in the United States from 1792 to and including 1907 was $143,725,839$ ounces, válued at $\$ 2,97 \mathrm{I}, 07 \mathrm{I}, 000$.

The important production of silver beginning about 1860 reached its maximum of $63,500,000$ ounces in 1892 , since which time the average annual production has been about 55,000,000 ounces. The total recorded production of silver ${ }^{5}$ in the United States is as follows: From I792 to $1847, \$ 404,500$; from 1848 to I 872 , \$157,749,900, and from I873 to and including I907, \$1,351,$84 \mathrm{I}, 600$; a total of $\mathrm{I}, 730,708,200$ ounces, valued at $\$ 1,509,996,000$.

The production of copper has for many years been steadily increasing. It reached its maximum in I906, when the output was nearly 918,000,000 pounds. Its production may be expected to increase largely in future years, as the uses of copper are increasing both in quantity and variety. The total production from 1860 to and including 1907 was about $12,075,000,000$ pounds. Its production by decades illustrates the rapid development of the industry, as follows:

For ten years, I86I-1870, about 218,504,000 pounds.

For ten years, I87I-I880, about 42I,I20,000 pounds.

For ten years, I88I-I890, about I,639,231,000 pounds.

For ten years, I89I-1900, about 4,348,71 3,000 pounds.

For seven years, I90I-I907, about $5,448,000,000$ pounds.

The production of lead and zinc during the past thirty years has increased rapidly, reaching a maximum in 1907 . The production of lead recorded for 1825 was I 500 short tons. The total production from 1830 to 1907 , inclusive, was $6,829,691$ short tons. The production by decades since 1830 illustrates the progress of the industry, as follows :

For ten years from 1830 to 1839 , inclusive, 122,500 short tons.

For ten years from 1840 to 1849 , inclusive, 247,000 short tons.

For ten years from 1850 to 1859 , inclusive, 168,800 short tons.

For ten years from 1860 to 1869 , inclusive, 153,900 short tons.

For ten years from 1870 to 1879 , inclusive, 547,780 short tons.

For ten years from 1880 to 1889 , inclusive, I, 345,7 II short tons.

For ten years from 1890 to 1899 , inclusive, I, 824,657 short tons.

For the 8 years from I900 to 1907 , inclusive, $2,417,843$ short tons.

sThese figures should be credited to R. W. Raymond for 1792 to 1873 , and to the U. S. Geological Survey for subsequent years.

$(692)$ 
The production of zinc (spelter) in 1873 was 7343 short tons. By 1875 it had reached 15,883 short tons. For the ten years from I 880 to I 889 , inclusive, the spelter production was $380,85^{2}$ short tons; from I 890 to I899, inclusive, it was 901,591 short tons, and for the eight years from I90o to 1907 , inclusive, it was $1,446,035$ short tons. This gives a total production from 1880 to 1907 , inclusive, of $2,75 \mathrm{I}, 654$ short tons.

The waste in the mining and treatment of gold, silver, lead and zinc has diminished as modern practice has grown in efficiency, but in many cases it is still large, in some cases amounting to nearly $5^{\circ}$ per cent. of the total possible product. The waste in the treatment of copper is generally less than that for the other of these metals, though the loss in the treatment of certain of the ores of copper exceeds 25 per cent., this being addlitional to losses in mining. Much of this waste in the mining and treatment of these metals is a temporary waste, the neglected and often buried low-grade ores, as well as the tailings, becoming available for treatment by later and more efficient processes.

Use and Waste of Structural Materials.-The supplies of many of the materials used in building and engineering construction, such as stone, sand, gravel, slate, clays, cement, lime, etc., are practically inexhaustible, and for that reason need not be extensively discussed.

The use of these materials has been restricted heretofore, especially in town and rural building, because of the greater cheapness of timber construction; but owing to improved methods the cost of buildings of concrete and other fire-resisting materials has been diminished, while that of wood products has advanced. Within the last decade the value of cement manufactures increased from $\$ 9,900,000$ to $\$ 55,900,000$ for the year, or nearly sixfold, and the value of clay products from $\$ 74,500$,000 to $\$ 159,000,000$, or more than dotible. In the same period the value of building stone increased from $\$ 28,600,000$ to $\$ 71,100,000$, or nearly threefold. A still larger relative increase in the use of these more durable build. ing materials may be looked for during the next several decades, since the Government is determining the strength, durability and fire-resistant properties of these materials, and is thus gaining and disseminating information which will serve as a basis of cheaper and more permanent structures.

The waste of minerals used in building and engineering con- 
struction comprises (I) that due to improper and wasteful methods of mining or quarrying and preparing for market; (2) that due to the use of excessive quantities of material because of a lack of knowledge concerning strength and durability; and (3) that due to destruction by fire. The losses from the last cause alone during I907, due to the direct burning of buildings and their contents, were $\$ 215,000,000$.

Other Mineral Substances.-The scope of the present article does not permit any extended discussion of the production and waste of other less-important mineral substances, of which, as mentioned above under the several classes, some 50 or 60 are produced and used in our industries. However, attention may be called to the fact that of certain of these, such as bauxite, corundum, mica, the ores of manganese, chromium, tin, platinum, antimony, tungsten, etc., the production in the United States is already inadequate for our industrial needs, and the domestic supplies of these materials, even though mined and used with the greatest efficiency, will probably always need to be supplemented or replaced by substitutes or by importations from other countries.

Other materials, such as asphalt, sulphur, magnesite, ochre, borax, talc and arsenic, are found in such quantities that even at the present increasing rates of production the supplies of these materials may be expected to meet the needs of the nation beyond the limits of the present century. There are still other mineral substances, such as clays, fullers' earth, grindstones and other abrasive substances, feldspar, salt, gypsum, etc., of which, notwithstanding their importance and the increasing rate of their production, the domestic supplies may be expected to meet all future demands.

Will the Increase in Mineral Production Continue? - Attention has been called above to the continued increase both in the total mineral production and in the per capita mineral production of the country. It is interesting to note in this connection that there has been a correspondingly marked increase in the per capita consumption of mineral products. The consumption of such products has increased far more rapidly than the population. Thus, in 1880 we used of coal 1.4 tons per capita; in I890, 2.3 tons; in I900, 3.2 tons, and in $1907,4.7$ tons. $^{6}$ Of pig iron we used in 1880,200 pounds per capita; in 1890,320 pounds; in 1900,391 pounds, and in 1907,686

-Figures for fiscal years, taken from Reports of the U.S. Bureau of Statistics, for both coal and iron. 
pounds. Of copper in 1890 we used 3 pounds per capita; in 1900 , 4.6 pounds, and in $1907,6.4$ pounds. Of cement we used in 1890,70 pounds per capita; in 1900, 92 pounds per capita, and in 1907, 228 pounds per capita.

The population of this country has increased from $5,308,000$ in I800 to $75,569,000$ in I900. After a careful study of the details in connection with this increase and the conditions under which this has come about, and a careful comparison of these conditions with those in the more densely populated countries of Europe where similar resources and climatic conditions maintain, Mr. Henry Gannett, of the United States Geological Survey, has estimated that the population of this country will be in $1910,90,000,000$; in 1950, about I50,000,000, and in the year 2000, approximately, 250,000,000.

In a further study of this question it should be borne in mind that during the past century the energies of the American nation were concerned largely with the conquest of the surface and other agricultural pursuits. Though the mining industry grew rapidly after the middle of the century, for years gold mining was the dominant feature. It was not until within the past quarter century that general mining and the use of mine products in manufacturing industries began to be a serious part of our national life and plans. Thus, for example, as late as I 880 the value of our coal product for that year was a little more than $\$ 95,000,000$, as compared to gold and silver production of about $\$ 71,000,000$, whereas in 1907 , with a gold and silver production of $\$ 128,000,000$, our coal production had reached $\$ 6 \mathrm{I}_{5}, 000,000$.

If, therefore, in connection with the rapid, realized and prospective increases in our population and the still more rapid increase in our per capita production and consumption of mineral products, we bear in mind the enormous resources of this country in fuels, iron and other essential mineral materials, the genius of our people for industry, and the extent to which climatic and other conditions favor manufacturing developments, one cannot fail to realize that this nation is to become more and more a great mining and manufacturing nation; that it must and will develop its varied domestic industries to supply not only its own growing needs, but also the demands of a large and steadily increasing export trade; thus extending and enlarging for generations to come the varied industries in which mineral products are used; and, therefore, that the per capita 
production and consumption of our mineral products will continue to increase for generations to come even more rapidly than our population. Already the products of the mine make up 65 per cent. of the total freight traffic of the country.

In order that we may be able to supply the raw materials for these increasing industries it will be necessary that we handle wisely our mineral supplies, not only preventing all unnecessary waste, but also practicing the highest possible efficiency in the use of these materials.

Extending the Life of Our Supplies.-The most important phase of the conservation problem is that concerned with the possibility of preventing unnecessary waste and of bringing about the most efficient use of our resources. We need to know how we can extend the life of these resources to meet the future as well as the present needs of the country. Investigation is undoubtedly the most important agency for the accomplishment of this purpose. Much has already been accomplished through this agency. The improvements brought about through the engineering profession during the past half a century in the manufacture of steel and other metallurgical operations and through increased efficiency in the development and operation of power plants, are already saving to the nation more than $100,000,000$ tons of fuel per annum. Through the work of the chemist and metallurgist in the improvement of technologic processes used in other metallurgical and manufacturing industries new and more efficient processes have made enormous savings in the resources of the country as well as in the capital required.

Three lines of investigation will prove useful in the continued development of these economies: ( $a$ ) a great number and variety of individual investigations of specific problems by the engineers and chemists in private practice; $(b)$ investigations of a more general but also somewhat local character by each of the several states in which are located extensive mining and metallurgical industries; $(c)$ investigations by the general government of those problems which on account of their general character may be of service to the mining, metallurgical and manufacturing industries throughout the country.

A number of such investigations by the federal government are already well under way, and are yielding important general results. 
Investigations by the states are for the most part limited to the exploration and mapping of local mineral resources. The private or individual investigations relate for the most part to specific individual problems connected with the development of specific local industries, and are intended for individual or private gain alone.

The common purpose of all these investigations must be to indicate $(a)$ how we can prevent waste; $(b)$ how the mineral products may be mined, treated and used with greatest efficiency; $(c)$ how more abundant materials may be substituted for the rarer and more costly materials.

Through careful educational work much also can be accomplished. In this work the federal and the state governments are coöperating, as are also, in an effective manner, the engineering and other allied organizations and the educational institutions throughout the country. Through wise legislation, also, much can be accomplished; but unless legislation is wisely planned and administered its influence may be more harmful than beneficial, as it may act in restraint of industry rather than by being helpful to its development.

Conservation and Legislation.-Self-interest will naturally continue to dominate the policies and activities of corporations, and these policies and activities, relating primarily to the question of temporary gain, may not always be in accord with the best interests of the community, the state or the nation. To the state and the nation alone can therefore be intrusted the ultimate guardianship of their own futures; and to this extent, at least, the conservation of resources becomes a state and, in a broader sense, a national duty and right. The United States Supreme Court, in a recent decision, says : "The state as the guardian of the public welfare possesses the constitutional right to insist that its natural advantages shall remain unimpaired by its citizens." And the federal constitution gives to Congress the right "to provide for the common defense and general welfare of the United States."

Any legislation in behalf of the wiser use of our resources should, however, be planned and drafted with care so as to guarantee for its provisions a remedial and beneficial rather than a harmful influence. The lack of uniformity in our state mining laws, even in the case of adjoining states where conditions are similar, is one of the unfortunate developments of our system. The 
differences have been based, probably, upon the mistaken idea that local mining conditions in different states require different local legislative treatment. As a matter of fact, under modern commercial conditions these differences between state laws may seriously hamper the mining industry in one or another of the states.

It would be helpful to the mining industry in all the states, and helpful to the conservation movement, if mining legislation in the different states could be made measurably uniform in its provisions, leaving for special, separate treatment the few really local problems. The benefits which have often resulted from conferences and wise coöperation between individuals or states, and even between nations, would become manifest in legislative as they have in other matters pertaining to the public welfare.

Both in legislation and in public opinion we must maintain as essential a rational basis for the conservation movement which recognizes ( $I$ ) the rights of the individual to property and to reasonable profits on his investments or on his labor, and (2) the paramount rights respectively of the community, of the state and of the nation to safeguard the future as well as the present welfare of its citizens. 